\title{
PEMBUATAN ASAP CAIR DARI BIOMASSA KULIT KOPI PADA KELOMPOK TANI PANGESTU RAKYAT KABUPATEN REJANG LEBONG
}

\author{
Deni Agus Triawan, Charles Banon, Morina Adfa, dan Ria Nurwidiyani \\ Fakultas Matematika dan Ilmu Pengetahuan Alam, Universitas Bengkulu \\ E-mail :deni_agust@ymail.com,deni.agustriawan@unib.ac.id
}

\begin{abstract}
ABSTRAK
Kegiatan pengabdian kepada masyarakat ini dilakukan dengan tujuan untuk mengoptimalkan pemanfaatan limbah kulit kopi pada Kelompok Tani Pangestu Rakyat Kabupaten Rejang Lebong dengan mengkonversinya menjadi asap cair. Kegiatan ini dilakukan dengan beberapa tahapan diantaranya penyampaian informasi dan pengetahuan kepada masyarakat tentang pembuatan asap cair dengan teknik pirolisis serta praktek/pelatihan pembuatan asap cair dan penggunaanya sebagai pestisida alami. Berdasarkan hasil pretest, informasi tingkat pemahaman peserta sebelum kegiatan dapat diketahui bahwa sebesar $90 \%$ peserta belum megetahui apa itu asap cair dan $10 \%$ peserta cukup mengetahui dan $0 \%$ peserta yang sangat mengetahui. Begitu pula tentang kulit kopi dapat dijadikan sebagai bahan pembuatan asap cair, cara pembuatan asap cair, teknik pirolisis dalam pembuatan asap cair serta penggunaan asap cair seluruh peserta (100\%) tidak mengetahui. Berdasarkan hasil posttest, diperoleh informasi bahwa seluruh peserta (100\%) telah mengetahui apa itu asap cair, kulit kopi dapat dijadikan sebagai bahan pembuatan asap cair, cara pembuatan asap cair, teknik pirolisis dalam pembuatan asap cair serta penggunaan asap cair. Berdasarkan data tersebut, diketahui bahwa kegiatan pengabdian kepada masyarakat tentang konversi kulit kopi menjadi asap cair multiguna telah berhasil dilakukan dan meningkatkan pemahaman masyarakat tentang informasi dan teknologi yang diberikan.
\end{abstract}

Kata Kunci: Kulit kopi, asap cair, pirolisis

\section{PENDAHULUAN}

Kelompok tani Pangestu Rakyat merupakan salah satu kelompok tani binaan Desa Baru Manis dengan bidang tanaman hortikultura terutama kopi, jagung, padi dan sayuran. Berdasarkan informasi dari Ketua Kelompok Tani, penanganan limbah organik kulit kopi oleh petani sejauh ini adalah dengan menumpuk limbah kulit kopi di pekarangan atau dibakar. Hal ini menjadi permasalahan sendiri di masyarakat dimana dapat menggagu kesehatan dan menyebabkan polusi udara. Selain itu, permasalahan yang dihadapi para petani adalah pada penanganan hama pada tanaman. Penggunaan pestisida berbahan kimia menjadi keluhan petani karena harga beli yang cukup tinggi dan resiko bagi kesehatan petani cukup tinggi pula. Kondisi ini menyebabkan tidak optimalnya produksi sayuran petani dan besarnya biaya produksi. Oleh 
karenanya, perlu suatu teknologi yang dapat menanggulangi kedua masalah diatas. Kulit kopi sebenarnya dapat dimanfaatkan untuk berbagai kebutuhan seperti kompos dan bahan pakan ternak (Triawan et al, 2020). Pemanfaatan kulit kopi menjadi asap cair multi guna dirasa dapat menjadi solusi yang tepat dalam menyelesaikan masalah ini. Rabitah (2013), telah melakukan penelitian tentang pembuatan asap cair dari limbah kulit kopi. Selain itu, Slamet \& Hidayat (2015) juga melakukan penelitian peroduksi asap cair dari kulit kopi dengan hasil asap cair sebesar 39,88\% dengan $93 \%$ senyawa asam. Berdasarkan hasil penelitian ini, asap cair kulit kopi sangat efektif digunakan sebagai pestisida alami. Proses pembuatan asap cair didasarkan pada proses pirolisis. Pada prinsipnya, proses pirolisis merupakan pemanasan suatu zat dengan oksigen terbatas sehingga terjadi penguraian komponen penyusunnya. Istilah lain dari pirolisis adalah destilasi kering dimana merupakan suatu proses yang tidak teratur dari bahan-bahan organik disebabkan oleh pemanasan yang tidak berhubungan dengan udara luar. Sebelumnya, asap cair juga sudah dibuat dengan berbahan cangkang kelapa sawit
(Saukani et al, 2017). Pengolahan kulit kopi dengan metode pirolisis akan menghasilkan asap cair yang dapat dimanfaatkan secara langsung oleh masyarakat. Penggunaan asap cair sangat beragam mulai dari pengawet makanan, pengawet kayu dan sebagai pestisida alami yang aman bagi manusia. Teknologi ini menjadi sangat penting bagi masyarakat untuk memanfaatkan limbah kulit kopi. Pengelolaan limbah organik (kulit kopi) menjadi asap cair multi guna ini memiliki beberapa keunggulan diantaranya meningkatkan nilai guna limbah kulit kopi menjadi asap cair yang dapat dimanfaatkan sebagai pestisida alami yang berdampak lanjut terhadap peningkatan ekonomi petani jika dikembangkan dalam volume yang lebih besar. Kegiatan pembuatan asap cair dari kulit kopi penting untuk dilakukan mengingat sampai saat ini teknologi pembuatan dan penggunaan asap cair ini masih belum diterapkan oleh masyarakat petani di kelompok mitra dan di Kabupaten Rejang Lebong pada umumnya.

\section{METODE PELAKSANAAN}

1. Persiapan, dilakukan koordinasi tim pengabdian dengan LPPM dan mitra sasaran pengabdian di 
Kabupaten Rejang Lebong, penyusunan jadwal kegiatan dan pembagian tugas masing-masing anggota

\section{Penyampaian informasi, diskusi} dan tanya jawab dilakukan dengan memberikan informasi dan pemahaman kepada masyarakat tentang pembuatan asap cair dari kulit kopi dengan metode pirolisis. Pada sesi ini, dilakukan diskusi terkait materi yang telah disampaikan sehingga masyarakat benar-benar paham tentang informasi yang diberikan.

\section{Pelatihan Pembuatan Asap Cair}

Untuk kegiatan pelatihan pembuatan asap cair, diperlukan peralatan dan bahan berupa biomassa kulit kopi, unit pirolisator, kondensor, pipa distribusi gas asap, penampung asap cair dan pemanas. Rangkaian alat pirolisis ini menyadur dari alat yang dirangkai oleh Mokhtar et al, 2018. Prosesnya adalah sebagai berikut:

a. Sebelum dimasukkan ke reaktor pirolisis, biomassa kulit kopi dibersihkan dari kotoran dan sabut yang tertinggal. Selanjutnya dilakukan pengeringan dengan cara penjemuran, untuk mengurangi kadar air pada biomassa kulit kopi.

b. Kemudian dilanjutkan dengan metode Pirolisis yang merupakan proses reaksi penguraian senyawa-senyawa penyusun kayu keras menjadi beberapa senyawa organik melalui reaksi pembakaran kering pembakaran tanpa oksigen. Reaksi ini berlangsung pada reaktor pirolisator yang bekerja pada temperatur $150-300{ }^{\circ} \mathrm{C}$ selama 8 jam pembakaran.

c. Asap hasil pembakaran dikondensasi dengan kondensor yang berupa koil melingkar. Hasil dari proses pirolisis diperoleh tiga produk yaitu asap cair, tar, dan arang. Kondensasi dilakukan dengan pipa tembaga berdiameter $10 \mathrm{~mm}$ yang dipasang dalam bak pendingin. Air pendingin menggunakan air sumur.

d. Asap hasil pembakaran biomassa dialirkan melalui pipa-pipa kecil atau tube dalam kondensor. Sedangkan air pendingin dialirkan di bagian luarnya atau didalam shell menggunakan sebuah pompa air. Parameter 
yang diukur adalah kapasitas

hasil pirolisis asap cair. Hasil asap cair ditampung dalam

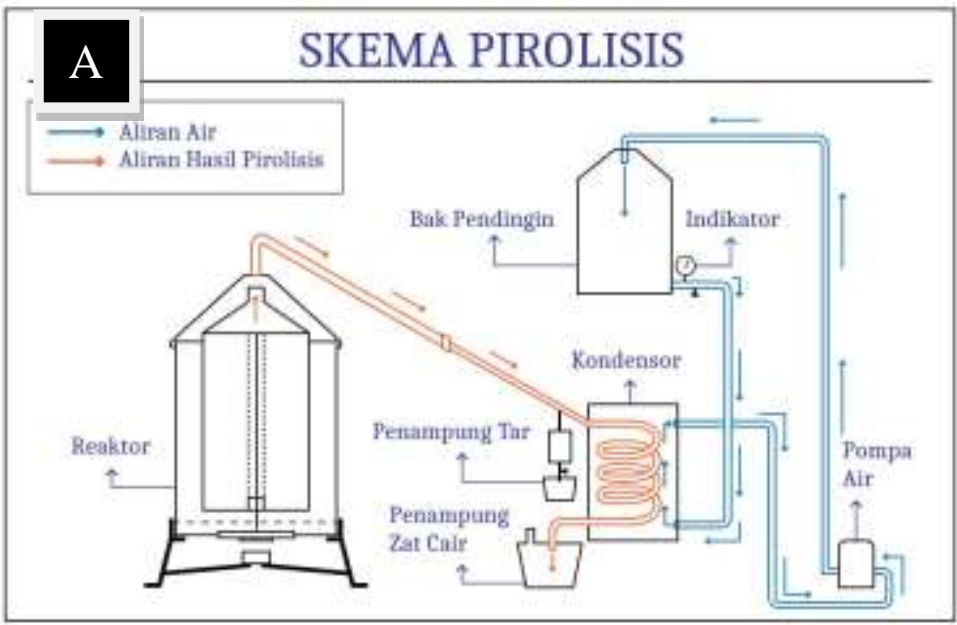

sebuah bejana yang kemudian bisa di ketahui volumenya.

Gambar 1. Skema alat pirolisis (a) Desain Mokhtar dkk, 2018; (b) alat yang dibuat

\section{HASIL DAN PEMBAHASAN}

Penyampaian informasi dilakukan dengan metode ceramah tentang proses pembuatan asap cair dan dilanjutkan dengan diskusi dan tanya jawab seputar kegiatan. Pada saat kegiatan, penyampaian informasi dapat dilakukan dengan baik yang ditunjukkan dari antusias warga masyarakat untuk mendengarkan, berdiskusi dan bertanya. Evaluasi pada saat pelaksanaan kegiatan dengan mengadakan pretest dan postest untuk mengetahui tingkat pemahaman dari peserta (mitra) sebelum dan setelah materi diberikan (Gambar 3).
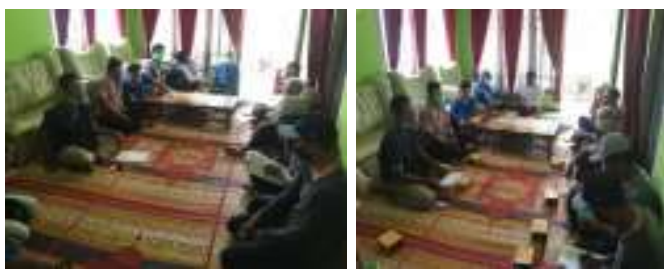

Gambar 3. Penyampaian Informasi tentang pembuatan asap cair dari kulit kopi

Setelah masyarakat mendapatkan informasi tentang pengolahan limbah kulit kopi menjadi asap cair multiguna, kegiatan dilanjutkan dengan kegiatan praktek pembuatan asap cair dengan menggunakan alat pirolisis. Antusias masyarakat dapat dilihat dari semangat dan keingintahuan proses pembuatan asap cair. Ketersedian bahan baku kulit kopi sangat melimpah di lokasi 
pengabdian karena potensi kopi daerah ini sangat tinggi.
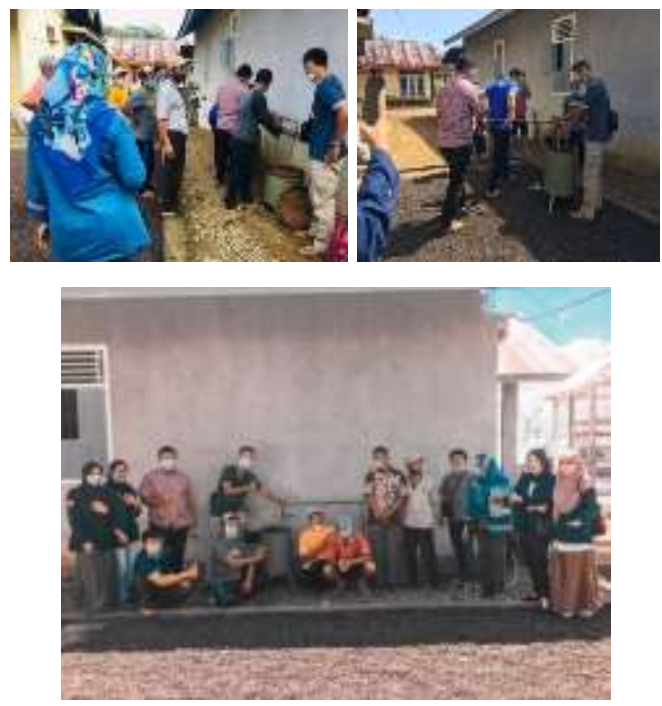

Gambar 4. Praktek pembuatan asap cair dari kulit kopi

Berdasarkan hasil pretest, informasi tingkat pemahaman peserta sebelum kegiatan dapat diketahui bahwa sebesar 90\% peserta belum megetahui apa itu asap cair dan $10 \%$ peserta cukup mengetahui dan $0 \%$ peserta yang sangat mengetahui. Begitu juga tentang pengetahuan bahwa kulit kopi dapat dijadikan asap cair tidak diketahui oleh peserta dimana $100 \%$ peserta tidak mengetahui. Pertanyaan selanjutnya tentang bagaimana cara membuat asap cair juga belum diketahui oleh peserta dimana $100 \%$ peserta menjawab tidak mengetahui cara pembuatan asap cair termasuk metode pirolisis dalam pembuatan asap cair. Penggunaan asap cair juga belum diketahui oleh peserta dimana $100 \%$ peserta menjawab tidak mengetahui.

Evaluasi juga dilakukan setelah kegiatan penyampaian informasi, diskusi dan tanya jawab serta pelatihan (praktek) pembuatan asap cair dari kulit kopi. Berdasarkan hasil posttest, diperoleh informasi bahwa seluruh peserta $(100 \%)$ telah mengetahui apa itu asap cair, kulit kopi dapat dijadikan sebagai bahan pembuatan asap cair, cara pembuatan asap cair, teknik pirolisis dalam pembuatan asap cair serta penggunaan asap cair. Berdasarkan data tersebut, diketahui bahwa kegiatan pengabdian kepada masyarakat tentang konversi kulit kopi menjadi asap cair multiguna telah berhasil dilakukan dan meningkatkan pemahaman masyarakat tentang informasi dan teknologi yang diberikan. 
Tabel 1. Hasil evaluasi tingkat pemahaman peserta sebelum kegiatan (pretest)

\begin{tabular}{|c|c|c|c|c|c|}
\hline \multirow[b]{2}{*}{ No } & \multirow[b]{2}{*}{ Pertanyaan } & \multicolumn{4}{|c|}{ Jawaban } \\
\hline & & $\begin{array}{c}\text { Tidak } \\
\text { Mengetahui }\end{array}$ & $\begin{array}{c}\text { Cukup } \\
\text { Mengetahui }\end{array}$ & Mengetahui & $\begin{array}{c}\text { Sangat } \\
\text { Mengetahui }\end{array}$ \\
\hline 1 & $\begin{array}{l}\text { Apakah bapak/ibu mengetahui } \\
\text { tentang asap cair? }\end{array}$ & 90 & 10 & 0 & 0 \\
\hline 2 & $\begin{array}{l}\text { Apakan bapak/ibu mengetahui } \\
\text { bahwa kulit kopi dapat } \\
\text { dijadikan asap cair? }\end{array}$ & 100 & 0 & 0 & 0 \\
\hline 3 & $\begin{array}{l}\text { Apakah bapak/ibu mengetahui } \\
\text { cara membuat asap cair? }\end{array}$ & 100 & 0 & 0 & 0 \\
\hline 4 & $\begin{array}{l}\text { Apakah bapak/ibu mengetahui } \\
\text { teknik pirolisis dalam } \\
\text { pembuatan asap cair? }\end{array}$ & 100 & 0 & 0 & 0 \\
\hline 5 & $\begin{array}{l}\text { Apakah bapak/ibu mengetahui } \\
\text { penggunaan asap cair? }\end{array}$ & 100 & 0 & 0 & 0 \\
\hline
\end{tabular}

Tabel 2. Hasil evaluasi tingkat pemahaman peserta setelah kegiatan (postest)

\begin{tabular}{clcccc}
\hline & \multicolumn{1}{c}{ Pertanyaan } & \multicolumn{3}{c}{ Jawaban } \\
\cline { 3 - 5 } $\mathbf{1}$ & $\begin{array}{c}\text { Tidak } \\
\text { Mengetahui }\end{array}$ & $\begin{array}{c}\text { Cukup } \\
\text { Mengetahui }\end{array}$ & Mengetahui & $\begin{array}{c}\text { Sangat } \\
\text { Mengetahui }\end{array}$ \\
\hline $\mathbf{2}$ & $\begin{array}{l}\text { Apakah bapak/ibu mengetahui } \\
\text { tentang asap cair? }\end{array}$ & 0 & 0 & 0 & 100 \\
$\begin{array}{l}\text { Apakan bapak/ibu mengetahui } \\
\text { bahwa kulit kopi dapat } \\
\text { dijadikan asap cair? }\end{array}$ & 0 & 0 & 0 & 100 \\
$\mathbf{3} \quad \begin{array}{l}\text { Apakah bapak/ibu mengetahui } \\
\text { cara membuat asap cair? }\end{array}$ & 0 & 0 & 0 & 100 \\
\hline $\begin{array}{l}\text { Apakah bapak/ibu mengetahui } \\
\text { teknik pirolisis dalam } \\
\text { pembuatan asap cair? }\end{array}$ & 0 & 0 & 0 & 100 \\
\hline $\begin{array}{l}\text { Apakah bapak/ibu mengetahui } \\
\text { penggunaan asap cair? }\end{array}$ & 0 & 0 & 0 & 100 \\
\hline
\end{tabular}

\section{KESIMPULAN}

Berdasarkan kegiatan yang telah dilakukan, dapat disimpulkan bahwa kegiatan pengabdian kepada masyarakat tentang konversi kulit kopi menjadi asap cair multiguna telah berhasil dilakukan dan meningkatkan pemahaman masyarakat tentang informasi dan teknologi yang diberikan pada kelompok tani
Pangestu Rakyat Kabupaten Rejang Lebong.

\section{UCAPAN TERIMAKASIH}

Penulis mengucapkan terimakasih kepada Universitas Bengkulu atas pendanaan kegiatan ini melalui dana PNBP UNIB Tahun 2020 dengan Nomor Kontrak : 2369/UN30.15/AM/ 2020. 


\section{DAFTAR PUSTAKA}

Afrizon, 2015, Potensi Kulit Kopi Sebagai Bahan Baku Pupuk Kompos Di Propinsi Bengkulu, AGRITEPA, Vol. II, No. 1, JuliDesember 2015

Antara Bengkulu, 2016, Produksi kopi Rejang Lebong Capai 13.402 Ton, edisi Selasa, 24 Mei 2016 14:38 WIB

Balai Pelatihan Pertanian Jambi, 2016, Teknologi Pengolahan Kopi. Jambi

Kusumawati, I \& Zuhro, F., 2019. Dampak Sosialisasi Aplikasi Asap Cair Organik Terhadap Pengendalian Bulai Tanaman Jagung Pada Kelompok Tani Karang Asem Indah Kabupaten Situbondo., BIO-CONS, Jurnal Biologi \& Konservasi, Vol. 1 No, 1 Juni 2019

Mokhtar, A., Jufri, M., \& Supriyanto, H., 2018., Perancangan Pirolisis Untuk Membuat Bahan Bakar Cair Dari Limbah Plastik Kapasitas $10 \mathrm{Kg}$., SENTRA, ISSN (2527-6050)

Rabitah, 2013, Aktivitas Anti Bakteri Asap Cair Dari Limbah Kulit
Kopi Terhadap Bakteri Pembusuk Pada Pisang Sale, Universitas Sumatera Utara: Tesis

Saukani, M., Arifin, J., Ihsan, S., \& Syahrillah, G.R.F., 2017., Pemanfaatan Limbah Kelapa Sawit Dalam Pembuatan Asap Cair Di Desa Jejangkit, Barito Kuala., Jurnal Pengabdian AlIkhlas, Vol. 2, No. 2.

Slamet, S., \& Hidayat, T., 2015, Studi Eksperimen Pemilihan Biomassa Untuk Memproduksi Gas Asap Cair (Liquid Smoke Gases) Sebagai Bahan Pengawet., Jurnal SIMETRIS, Vol. 6, No.. 1

Triawan, D.A., Banon, C., \& Adfa., M., 2020., Biokonversi Kulir Kopi Menjadi Pupuk Kompos Pada Kelompok Tani Pangestu Rakyat Kabupaten Rejang Lebong, Jurnal Pengabdian Al-Ikhlas, Vol. 5, No. 2.

Zuraida, I., Hasbulla., R., Sukarno., Budijanto, S., Prabawati, S., \& Setiadjit., 2009., Aktivitas Antibakteri Asap Cair Dan Daya Awetnya Terhadap Bakso Ikan., Jurnal Ilmu Pertanian Indonesia, Vol. 14, No. 1 